\title{
Dampak Promosi, Harga, Dan Diferensiasi Produk Dalam Meningkatkan Keputusan Pembelian
}

\author{
Syaiful Akbar, Herman Sjahruddin, Jannati Tangngisalu, Poppy Nahdia Syahrani Pascawati \\ Program Studi Manajemen pada Sekolah Tinggi Ilmu Ekonomi Bongaya Makassar \\ Email: syaifulakbar2309@gmail.com
}

\begin{abstract}
Abstrak
Studi ini mengeksplorasi pengaruh promosi, harga, dan diferensiasi produk terhadap keputusan pembelian. Dalam penelitian ini adalah produk brownies amanda. Populasi dalam penelitian ini adalah konsumen gerai Brownis Amanda Makassar. Pengambilan sampel menggunakan accidental sampling dengan penentuan waktu selama 2 minggu, sehingga dalam kurun waktu tersebut diperoleh 96 konsumen sebagai unit analisis. Pendekatan kuantitatif digunakan melalui penggunaan regresi berganda dengan menggunakan SPSS Statistics 25. Hasil analisis deskriptif memberikan bukti bahwa durabilitas adalah indikator diferensiasi produk yang paling penting, kesesuaian saran yang paling penting untuk promosi dan keterjangkauan harga merupakan indikator dominan dari harga dan evaluasi alternatif untuk keputusan pembelian. Hasil pengujian memberikan bukti bahwa semakin intens promosi yang dilakukan dan semakin tinggi diferensiasi produk maka berdampak nyata terhadap keputusan konsumen untuk melakukan pembelian, sebaliknya terbukti harga yang rendah mengakibatkan keputusan pembelian yang tinggi. .
\end{abstract}

Kata kunci: Keputusan pembelian, diferensiasi, promosi, harga

\begin{abstract}
This study explores the effect of promotion, price, and product differentiation on purchasing decisions. in this research is amanda brownie product. The population in this study were consumers of Brownis Amanda outlet in Makassar. Sampling used accidental sampling with a determination of time for 2 weeks, so that within that time 96 consumers were obtained as the unit of analysis. The quantitative approach is used through the use of multiple regressions using SPSS Statistics 25. The results of descriptive analysis provide evidence that durability is the most important indicator of product differentiation, appropriateness of the most important suggestions for promotion and affordability of prices are dominant indicators of price and evaluation of alternatives for purchasing decisions. The test results provide evidence that the more intense the promotions carried out and the higher the differentiation of the products, the real impact on the consumer's decision to make a purchase, on the other hand, it is proven that low prices result in high purchasing decisions.
\end{abstract}

Keywords : Purchasing decision, differentiation, promotion, price

\section{PENDAHULUAN}

Pada era yang serba sibuk saat ini, sesuatu yang praktis sangat dibutuhkan oleh masyarakat. Segala hal yang ada dibuat sedemikian praktis agar dapat menghemat banyak waktu. Seperti contoh, sekarang sudah banyak tempat yang menyuguhkan makana cepat saji tanpa harus sibuk memasak di dapur. Mulai dari makana ringan hingga makan pokok. Fenomena seperti inilah yang membuat indutri makanan tumbuh subur di Indonesia. Peluang industri pangan di dalam negeri sendiri berkembang pesat dan cukup menjanjikan.

Dalam persaingan indutri makanan, khususnya kue, ada satu jenis makanan yang banyak dilirik oleh konsumen yaitu kue brownis. Kue jenis ini mudah disukai konsumen . kue ini juga bias karena memiliki rasa cokelat yang pekat dan tekstur yang lembut, kue ini juga bisa dinikmati oleh konsumen berbagai usia baik muda maupun tua. Saat ini rasa brownis pun sudah memiliki 
berbagai varian bukan hanya rasa cokelat original saja. Pada industri makanan ringan ada satu nama yang patut diperhitungkan yaitu Brownis Amanda Kukus. Brownis Amanda merupakan salah satu pilihan kuliner yang memiliki ciri khas dengan kualitas produk yang tinggi dan sangat cocok untuk oleh-oleh. Selain untuk oleh-oleh, brownis Amanda juga disajikan dalam pertemuan rapat, arisan, maupun ulang tahun.

Alasan dilakukannya studi ini dikarenakan dalam segi promosi dan harga, karena pesaing usaha brownies di Kota Makassar sangat terbatas sementara disisi lain perusahaan dalam melakukan penjualan, capaian penjualan senantiasa berada dibawah dari yang ditargetkan. Sementara disisi lain perusahaan telah melakukan diferensiasi produk sejak tahun 2019 ini. Differensiasi produk yang dilakukan terlihat dengan adanya 13 varian rasa yang ditawarkan kepada konsumen, antara lain brownies original, sarikaya pandan, choco marble, pink marble, bluberry, brownies tiramisu, cappucino marble, tiramisu marble, chese cream, dan brownies bakar. Dari semua produk tersebut, yang paling laris terjual yakni brownies original. Berdasarkan diferensiasi produk tersebut, penjualan Amanda Brownies di perkirakan berkisar 500 boks hingga 1.000 boks. Dari segi Harganya juga terjangkau, mulai dari Rp 40 ribu hingga Rp 69 ribu. Dan diperkirakan saat hari raya Idul Fitri penjualan meningkat pesat hingga 10 kali lipat (Tribunnews, 2019).

Berdasarkan observasi yang telah dilakukan tersebut, peneliti menemukan fenomena yang menggambarkan kelemahan penggunaan diferensiasi pada produk yang dimana diferensiasi dapat menciptakan pemborosan sumber daya yang langka karena diferensiasi memerlukan biaya yang besar, konsumen membayar produk yang terdiferensiasi dengan harga yang lebih mahal karena iklan merupakan bagian dari diferensial, konsumen dapat memperoleh informasi yang salah tetang produk yang diiklankan karena iklan dimaksudkan untuk mengubah preferensi (kesukaan) konsumen dan menciptakan kebutuhan yang sebenarnya tidak ada, dan masyarakat dapat terganggu dan bosan dengan banyaknya iklan yang disampaikan melalui berbagai media secara berulang-ulang (Syarif edri Alydrus, 2019).

\section{Promosi}

Promosi merupakan salah satu faktor penentu keberhasilan progam pemasaran atau strategi pemasaran hal ini dikarenakan promosi adalah komunikasi yang persuasif, mengajak, mendesak, membujuk dan meyakinkan seseorang (Mursid, 2016:96). Promosi adalah suatu komunikasi dari penjual dan pembeli yang berasal dari informasi yang tepat dan bertujuan untuk merubah sikap dan tingkah laku pembeli. Promosi adalah usaha yang dilakukan pemasar untuk mempengaruhi pihak lain agar berpartisipasi dalam kegiatan pertukaran. Promosi juga merupakan usaha mengkomunikasikan informasi yang bermanfaat tentang suatu perusahaan atau produk dan jasa untuk mempengaruhi pembeli potensial (Tjiptono, 2014: 219).

Promosi adalah arus informasi atau persuasi satu arah yang dapat mengarahkan organisasi atau seseorang untuk menciptakan transaksi antara pembeli dan penjual. Promosi merupakan kegiatan terakhir dari marketing mix yang sangat penting karena sekarang ini kebanyakan pasar lebih banyak bersifat pasar pembeli dimana keputusan terakhir terjadinya transaksi jual beli sangat dipengaruhi oleh konsumen (Daryanto, 2011:94). Oleh karena itu, pembeli adalah raja. Tujuan utama dari promosi adalah modifikasi tingkah laku konsumen, menginformasikan, mempengaruhi, dan membujuk serta mengingatkan konsumen sasaran tentang perusahaan dan produk atau jasa yang dijualnya (Swastha dan Irawan, 2006; dalam Widagdo, 2011:3).

\section{Harga}

Harga merupakan jumlah semua nilai yang diberikan oleh pelanggan untuk mendapatkan keuntungan dari memiliki atau menggunakan suatu produk atau jasa (Kotler dan Keller, 2016:345). Harga mempunyai peranan penting bagi konsumen dalam mempertimbangkan pembelian. Hal itu mengingat harga merupakan salah satu faktor yang diperhitungkan konsumen dalam menentukan intensitas pembelian (Fika, 2012:98).

Perusahaan dituntut untuk mempertimbangkan banyak faktor dalam 
menyusun kebijakan menetapkan harga (Thamrin Abdullah, 2012:171), antara lain:

1. Pemilihan sasaran harga perusahaan, pertama-tama harus memutuskan apa yang ia ingin capai dengan suatu produk tertentu. Jika perusahaan tersebut telah memilih pasar sasaran dan penentuan posisi pasarnya dengan cermat, maka strategi bauran pemasaranya, termasuk harga, akan cukup mudah.

2. Penentuan permintaan, setiap harga yang di tentukan perusahaan akan membawa kepada tingkat permintaan yang berbeda dan oleh karenanya akan mempunyai pengaruh yang berbeda terhadap sasaran pemasaranya. Skedul permintaan menggambarkan jumlah unit yang akan di beli oleh pasar pada periode tertentu atas alternatif harga yang mungkin ditetapkan selama periode itu.

3. Prediksi atas harga, permintaan umumnya membatasi harga tertinggi yang dapat di tentukan perusahaan bagi produknya. Dan perusahaan menetapkan biaya yang terendah. Perusahaan ingin menetapkan harga yang dapat menutupi biayanya dalam menghasilkan, mendistribusikan, dan menjual produk, termasuk pendapatan yang wajar atas usaha dan risiko yang dihadapinya.

\section{Diferensiasi Produk}

Produk merupakan segala sesuatu yang dapat ditawarkan ke pasar untuk mendapatkan perhatian, dibeli, digunakan atau dikonsumsi yang dapat memuaskan keinginan atau kebutuhan (Kotler dan Keller, 2016). Produk menurut ahli dijelaskan sebagai segala sesuatu yang dapat ditawarkan oleh produsen ke konsumen untuk diperhatikan, diminta, dicari, dibeli, digunakan, dipakai atau dikonsumsi pasar sebagai pemenuhan kebutuhan atau keinginan pasar yang bersangkutan (Tjiptono, 2014: 95).

Diferensiasi produk merupakan strategi yang membuat produk berbeda dengan kompetitor bahkan melebihinya sehingga hasil yang dapat dinilai oleh konsumen dan nilai yang diharapkan dapat memengaruhi pilihan dan kepentingan konsumen yang paling istimewa. Konsumen merasa puas ketika mereka memperoleh produk yang dapat memenuhi harapan mereka atau bahkan melebihinya dibandingkan dengan produk pesaing (Heru, 2016: 26). Penciptaan suatu produk atau citra produk yang cukup berbeda dengan produk yang telah beredar dengan maksud untuk menarik konsumen (Dejawata dkk, 2014: 2). Dari pernyataan tersebut, dapat dikatakan bahwa diferensiasi merupakan kegiatan yang dilakukan oleh perusahaan dalam menghasilkan dan memasarkan produk yang berbeda dari tawaran pesaing. Perbedaan yang diciptakan mempunyai keunggulan nilai dan manfaat lebih untuk memenuhi kebutuhan pelanggan.

\section{Konsep Keputusan Pembelian}

Secara khusus keputusan pembelian merupakan tahap dalam proses pengambilan keputusan pembeli dimana konsumen benar-benar akan membeli. Berdasarkan tujuan pembelian, konsumen dapat diklasifikasikan menjadi dua kelompok, yaitu konsumen akhir (individual) dan konsumen organisasional (konsumen industrial, konsumen antara, konsumen bisnis). Konsumen akhir terdiri atas individu atau rumah tangga yang tujuan akhirnya adalah untuk memenuhi kebutuhan sendiri atau untuk konsumsi. Sedangkan konsumen organiasional terdiri atas organisasi, pemakai industri, pedagang dan lembaga non profit yang tujuan pembeliannya adalah untuk keperluan bisnis (memperoleh laba) atau meningkatkan kesejahteraan anggotanya. Keputusan pembelian konsumen dipengaruhi oleh perilaku konsumen (Kotler dan Keller, 2016:94).

Perusahaan harus mengenali perilaku konsumen untuk mengetahui apa yang dibutuhkan oleh konsumen, sehingga perusahaan diharapkan dapat selalu memenuhi kebutuhan konsumen yang akan berdampak pada loyalitas.

\section{METODE PENELITIAN}

Penelitian kuantitatif ini bersandar pada metode survey yang berlandaskan 
filasafat positivisme, digunakan untuk meneliti pada populasi atau sampel tertentu, teknik penarikan sampel dilakukan dengan cara random, pengumpulan data menggunakan instrument penelitian, analisis data bersifat kuantitatif yang bertujuan untuk menguji hipotesis yang telah ditetapkan. Penelitian ini juga mengunakan penelitian konklusif yang bersifat kausal yaitu suatu penelitian yang mempunyai tujuan untuk menguji suatu hipotesis yang spesifik atau jelas dengan menampilkan hubungan sebab akibat (Sugiyono, 2017: 14).

\section{HASIL}

\section{Keabsahan dan kehandalan data}

Validitas merupakan derajat ketepatan antara data yang terjadi pada obyek penelitian dengan data yang dapat dilaporkan oleh peneliti”. Untuk mengtahui apakah data yang digunakan valid dengan membandingkan antara rhitung dengan rtabel dengan tingkat kesalahan (signifikan) 5\% (Sugiyono, 2017:267).

Tabel 1. Keabsahan variabel penelitian

\begin{tabular}{|c|c|c|c|}
\hline Konstruk & Korelasi & Kebermaknaan & Kehandalan \\
\hline Promosi_1 & $.915^{* *}$ & .000 & \multirow{2}{*}{$.906^{* *}$} \\
\hline Promosi_2 & $.917^{* *}$ & .000 & \\
\hline Promosi_3 & $.871^{* *}$ & .000 & \multirow{2}{*}{.} \\
\hline Promosi_4 & $.838^{* *}$ & .000 & \\
\hline Harga_1 & $.808^{* *}$ & .000 & \\
\hline Harga_2 & $.666^{* *}$ & .000 & \\
\hline Harga_3 & $.832^{* *}$ & .000 & \multirow{2}{*}{$.853^{* *}$} \\
\hline Harga_4 & .792 & .000 & \\
\hline Differensiasi_1 & $.941^{* *}$ & .000 & \multirow{2}{*}{$.752^{* *}$} \\
\hline Differensiasi_2 & $.810^{* *}$ & .000 & \\
\hline Differensiasi_3 & $.883^{* *}$ & .000 & \\
\hline Keputs_1 & $.858^{* *}$ & .000 & \\
\hline Keputs_2 & $881^{* *}$ & .000 & \\
\hline Keputs_3 & $.710^{* *}$ & .000 & \\
\hline
\end{tabular}

Indikator variabel variabel analisis, promosi (X1), harga (X2) dan diferensiasi (X3) serta keputusan pembelian (Y) memiliki nilai person correlation $(r=>0,30)$ dan tingkat signifikansinya $(\alpha=<0,05)$. Dengan begitu maka dapat dinyatakan seluruh indikator Keputusan Pembelian (Y) memenuhi syarat validitas.

Uji reliabilitas dilakukan untuk menguji apakah jawaban dari responden konsisten atau stabil, suatu variabel dikatakan reliabel jika memiliki nilai cronbach alpha $>0,60 "$ (Ghozali, 2016). Hasil analisis menunjukkan seluruh variabel memiliki nilai kehandalan $>0,60$

\section{Kesesuaian Data Kenormalan}

Uji Normalitas digunakan untuk mengetahui model regresi berdistribusi normal atau tidak. Pengujian normalitas dalam data penelitian ini menggunakan analisis Kolmogorov-smirnov, nilai t-stat $=$ $0.067>0.05$ dan nilai p-value $0.200>$ 0.05. dengan demikian pengujian regresi untuk variabel pengamatan memenuhi syarat kenormalan.

\section{Gangguan hubungan data}

Multikolineritas bertujuan untuk menguji apakah model regresi ditemukan adanya korelasi antar prediktor, model regresi yang baik seharusnya tidak terjadi korelasi diantara determinan pengamatan, (Ghozali, 2016). Pengujian membuktikan jika promosi memiliki nilai tolerance dan influence factor :

Tabel 2. Gangguan hubungan

\begin{tabular}{|l|r|r|}
\hline Konstruk & Tolerance $<1$ & Influence factor $<10$ \\
\hline Promosi & 0.454 & 2.204 \\
\hline Harga & 0.313 & 3.192 \\
\hline Differensiasi & 0.326 & 3.07 \\
\hline
\end{tabular}

Nilai tolerance analisis data keseluruhan $<1$ dan nilai faktor hubungan < 10 sehingga dapat disimpulkan tidak terjadi multikoloneritas. Sehingga salah satu syarat uji regresi berganda telah terpenuhi.

\section{Keragaman dana}

Uji heteroskedastisitas bertujuan menguji apakah dalam model regresi terjadi ketidaksamaan variance dari 
residual satu pengamatan ke pengamatan yang lain", (Ghozali, 2016:139). Ada atau tidak adanya gejala heteros dengan melihat pada tabel berikut ini:

Tabel 3. Keseragaman data

\begin{tabular}{|l|c|c|}
\hline Konstruk & $t$-hit & $p$-value \\
\hline Promosi & -.182 & .856 \\
\hline Harga & -1.069 & .288 \\
\hline Differensiasi & -.157 & .875 \\
\hline
\end{tabular}

Nilai kebermaknaan pada pengujian heteroskedastisitas untuk variabel diferensiasi, promosi dan harga secara keseluruhan $>0.05$, maka dapat disimpulkan bahwa model regresi dalam penelitian ini tidak terjadi heteroskedastisitas.

\section{Pengujian pemodelan}

Nilai F-hit. yang diperoleh $=173.421$ sementara F-tab. pada tingkat kepercayaan 95\% dan derajat bebas $=3$ (df1) dan 93(df2) yang diperoleh dari (3:96-3-1 = 92) maka diporeh nilai Ftab. 3,155 oleh karena itu F-hit. $173.421>$ F-tab. 3,155 maka data analisis telah memenuhi syarat pemodelan

\section{Pengujian hipotesis}

Perbandinan nilai t-hit dengan t-tab digunakan dalam membuktikan hipotesis yang diajukan, seperti yang disajikan dibawah ini:

Tabel 4. Hipotesis test

\begin{tabular}{|l|c|r|}
\hline Konstruk & $t$-hit & $p$-value \\
\hline Promosi & 2.641 & .010 \\
\hline Harga & -4.373 & .000 \\
\hline Differensiasi & 14.779 & .000 \\
\hline
\end{tabular}

Pengaruh masing-masing predikto pada variabel terikat, dapat dilakukan dengan melihat nilai beta standardized, $\mathrm{t}$ hitung > t-tabel $(1,985)$ yang diperoleh dari 96-1-1=94 $(5 \%, 94)$ dan $\alpha<0.05$ berarti Ho ditolak dan Ha diterima, lebih jelasnya dapat diuraikan sbagai berikut :
1. Promosi (X1) pada keputusan pembelian (Y), sebesar 2.641 dengan nilai signifikan sebesar 0,010 pada $\propto=0,05$, maka promosi berpengaruh positif dan signifikan terhadap keputusan pembelian.

2. Harga (X2) pada keputusan pembelian (Y), sebesar -4.373 dengan nilai signifikan sebesar 0,000 pada $\propto=0,05$ sehingga dapat dinyatakan jika harga berpengaruh negatif dan tidak signifikan terhadap keputusan pembelian.

3. Diferensiasi (X3) pada keputusan pembelian (Y), sebesar 14.779 dengan nilai signifikan sebesar 0,000 pada $\propto=0,05$ bahwa diferensiasi berpengaruh positif dan signifikan terhadap keputusan pembelian.

\section{Pembahasan \\ Pengaruh promosi terhadap keputusan pembelian}

Pengaruh promosi terhadap keputusan pembelian dapat dibuktikan dengan nilai koefisien yang tidak terstandarisasi sebesar 0,171, dan nilai koefisien terstandarisasi sebesar 0,158 , nilai koefisien tersebut bertanda positif yang menjelaskan semakin tinggi promosi maka semakin tinggi pula keputusan pembelian. Hasil tersebut didukung dengan nilai thitung sebesar 2.641> t-tabel $=1,985$ dengan nilai signifikansi $p$-value sebesar $0,010<0,05$, hasil tersebut membuktikan bahwa promosi berpengaruh positif dan signifikan terhadap keputusan pembelian pada outlet brownies amanda kota makassar.

Hasil penelitian ini sejalan dengan penelitian yang dilakukan oleh Tajudin dan Mulazid (2017), bahwa secara promosi berpengaruh signifikan terhadap keputusan pembelian. Signifikannya hasil tersebut disebabkan karena perusahaan berdasarkan responden dipandang sangat gencar melakukan aktivitas promosi pada media social sehingga promosi yang disajikan dengan sejelas-jelasnya oleh responden dipandang dapat memicu keinginan konsumen untuk memutuskan dilakukannya pembelian. 


\section{Pengaruh harga terhadap keputusan pembelian}

Harga pada keputusan pembelian dapat dibuktikan dengan nilai koefisien yang tidak terstandarisasi $=-0,334$, dan nilai koefisien terstandarisasi $=-0,316$, nilai koefisien tersebut bertanda negatif yang menjelaskan semakin rendah harga maka semakin tinggi keputusan pembelian. Nilai t-hit. $=-4.373>\mathrm{t}$-tab.= 1,985 dengan nilai signifikansi $p$-value sebesar $0,00<0,05$, bahwa harga berpengaruh negatif dan signifikan terhadap keputusan pembelian. Kondisi ini disebakan karena perusahaan mengetahui kebutuhan dan keinginan konsumen, pengetahuan tersebut diperoleh dari layanan pengaduan yang diberikan kepada konsumen, bahwa konsumen memiliki kemampuan terbatas dalam hal harga sehingga perusahaan memberikan banyak alternative produk yang kemudian menjadi sandaran konsumen dalam memutuskan pembelian, studi ini relevan dengan temuan Sjahruddin (2018), bahwa harga yang rendah menjadi pemicu dilakukannya pembelian dengan tetap menjaga kualitas produk.

\section{Pengaruh diferensiasi terhadap keputusan pembelian}

Diferensiasi pada keputusan pembelian dapat dibuktikan dengan nilai koefisien yang tidak terstandarisasi $=0,897$, dan nilai koefisien terstandarisasi $=1.047$, nilai koefisien tersebut bertanda positif yang menjelaskan semakin tinggi diferensiasi maka semakin tinggi pula keputusan pembelian. Temuan ini terlihat pada nilai $\mathrm{t}$-hit. $=14.779>\mathrm{t}$-tab. 1,985 dengan kebermaknaan $=0,00<0,05$, hasil tersebut membuktikan bahwa diferensiasi berpengaruh positif dan signifikan terhadap keputusan pembelian. Hasil yang signifikan diakibatkan karena banyaknya keragaman variasi produk yang ditawarkan mulai dari jenis dan harga sehingga dengan kondisi tersebut perusahaan tidak hanya melakukan differensiasi pada produk semata namun juga pada varian harga. Studi ini mendukung penelitian Yulianti (2017) bahwa keaneka ragaman produk yang ditawarkan menjadi pemicu dilakukannya pembelian.

\section{Simpulan}

Promosi yang tinggi (sering) berdampak nyata pada keputusan pembelian, sedangkan harga yang rendah menjadi alasan dilakukannya pembelian serta diferensiasi yang beragam varians mengakibatkan dilakukan keputusan pembelian. Keinginan untuk melakukan aktivitas promosi pada media social sehingga promosi yang disajikan dengan sejelas-jelasnya oleh responden dipandang dapat memicu keinginan konsumen untuk memutuskan dilakukannya pembelian. Tuntutan untuk mengetahui kebutuhan dan keinginan sangat penting karena dengan informasi tersebut diperoleh informasi, bahwa konsumen memiliki kemampuan terbatas dalam hal harga sehingga perusahaan memberikan banyak alternative produk yang kemudian menjadi sandaran konsumen dalam memutuskan pembelian. Keragaman produk yang ditawarkan mulai dari jenis dan harga sehingga dengan kondisi tersebut perusahaan tidak hanya melakukan differensiasi pada produk semata namun juga pada varian harga.

Studi ini merekomendasikan kepada perusahaan untuk tidak hanya menayangkan iklannya pada social media semata tetapi juga menggunakan media elektronik sehingga dengan promosi yang gencar dengan dukungan gaya bahasa yang jelas serta desain yang semenarik mungkin maka konsumen merasa penasaran dan tertarik untuk melakukan pembelian, Perusahaan diharpakan memberikan label harga pada kemasan sehingga konsumen lebih mudah untuk mengetahui harga setiap varian yang ada karena konsumen juga harus mengetahui detail harga sebelum membeli serta dapat menyesuaikan dengan standar budget konsumen, 


\section{DAFTAR PUSTAKA}

[1] Agus Harjito dan Martono. (2010). Manajemen Keuangan. Yogyakarta: Ekonisia.

[2] Daryanto. (2011). Sari Kuliah Manajemen Pemasaran.Bandung:PT Sarana Tutorial Nurani Sejahtera.

[3] Dejawa, Thariz Baharmal (2014).Pengaruh Diferensiasi Produk Terhadap Kepuasan Pelanggan dan Loyalitas Pelanggan”.Jurnal.Malang: Fakultas Ilmu Administrasi Universitas Brawijaya.

[4] Fika Ermawati. (2012). Pengaruh Kualitas Pelayanan, Harga Dan Ketersediaan Produk Dalam Pembentukan Intensitas Pembelian Konsumen Pada Makanan Kepiting Di Rumah Makan Sampan Seafood Semarang”. Jurnal Dinamika Manajemen, 1 (5). 93-107

[5] Ghozali, I. (2016). Aplikasi Analisis Multivariete Dengan Program. IBM SPSS 23 (Edisi 8). Cetakan ke VIII. Semarang: Badan Penerbit Universitas Diponogoro.

[6] Heru, Hevri. (2016). Pengaruh Diferensiasi Produk, Citra Merek, dan Harga Terhadap Keputusan Pembelian Sepeda Motor Yamaha (Studi kasus pada pengguna sepeda motor Yamaha di Kota Tangerang)”. Jurnal.Jakarta: Fakultas Ekonomi dan Bisnis Universitas Mercu Buana.

[7] Koran Makassar. (2018). Buruan, Ada Paket Hemat Amanda Brownies, Segini Harganya.https://makassar.terkini.id/burua n-ada-paket-hemat-amanda-browniessegini-harganya/. Diakses pada Agustus 2019

[8] Kotler, Philip dan Kevin Lane Keller, (2016). Marketing Management, 15thEdition New Jersey: Pearson Pretice Hall, Inc.
[9] Mursid. (2015). Manajemen Pemasaran. Jakarta: Bumi Aksara.

[10] Sugiyono. (2017). Metode Penelitian Kuantitatif, Kualitatif,dan R\&D. Bandung: CV. Alfabeta

[11] Sjahruddin, H. (2018). Kepuasan Konsumen: Implementasi Kualitas Layanan dan Harga Jual Mobil Kepuasan Konsumen. Jurnal Manajemen dan Organisasi 2(1). 7889

[12] Syarif edri Alydrus. (2019). Kelemahan diferensiasi produk (Oligopoli). https://www.academia.edu/12242994/Kele mahan_diferensiasi_produk_Oligopoli_.

Diakses pada Agustus 2019

[13] Tajudin, M. H., dan Ade S. M. (2017), Pengaruh Promosi, Kepercayaan Dan Kesadaran Merek Terhadap Keputusan Nasabah Menggunakan Produk Tabungan Haji (Mabrur) Bank Syariah Mandiri Kcp. Sawangan Kota Depok. Jurnal Ekonomi Islam. Volume 8 No. 1

[14] Thamrin Abdullah dan Francis Tantri, (2012). Manajemen Pemasaran, Jakarta : PT Rajagrafindo Persada.

[15] Tjiptono, Fandy. (2014), Pemasaran Jasa - Prinsip, Penerapan, dan Penelitian, Andi Offset, Yogyakarta.

[16] Tribunnews (2019). Amanda Brownies Samarinda Pindah Outlet ke Jl Ahmad Yani, Tersedia Promo Berhadiah Dua Produk Ini. https://kaltim.tribunnews.com/2019/04/26 /amanda-brownies-samarinda-pindahoutlet-ke-jl-ahmad-yani-tersedia-promoberhadiah-dua-produk-ini. Diakses pada Agustus 2019

[17] Widagdo, Herry. (2011). "Analisis Pengaruh Kualitas Layanan dan Promosi Terhadap Keputusan Konsumen Membeli Komputer Pada PT. XYZ Palembang". Jurnal Ilmiah STIE MDP Vol. 1 No. 1 September. 
[18] Yulianti, L., Sjahruddin, H., dan Tahir, B. (2017). Implementasi Customer Relationship Management (CRM) Terhadap Kepuasan dan Loyalitas Pelanggan
Pengguna Samsung. 